Моделювання методичної системи формування ІКТ-компетентності майбутніх фахівців галузі «Культура і мистецтво»

УДК 378.147:7.01

\title{
МОДЕЛЮВАННЯ МЕТОДИЧНОЇ СИСТЕМИ ФОРМУВАННЯ ІКТ-КОМПЕТЕНТНОСТІ МАЙБУТНІХ ФАХІВЦІВ ГАЛУЗІ «КУЛЬТУРА І МИСТЕЦТВО»
}

\author{
Федір Апшай \\ аспірант \\ Рівненський державний гуманітарний університет, \\ м. Рівне, Україна \\ ORCID ID 0000-0002-9789-464X \\ apshar_fv@ukr.net
}

\begin{abstract}
Анотація. Підготовка фахівців у галузі «Культури і мистецтва» до діяльності в інформаційному суспільстві розглянуто в контексті інтеграції інформаційно-комунікаційних технологій (IКT) в освітній процес, де їх навчають використовувати сучасні засоби IКТ для вирішення практичних професійних завдань і здійснення професійної діяльності. У структурі ІКТ-компетентності майбутніх фахівців у галузі «Культура i мистецтво» включені такі складники: особистісно-мотиваційний, когнітивний, діяльнісний, рефлексивний. Відповідно до методичної системи включено сукупність взаємопов'язаних і взаємообумовлених блоків: цільового, аналітико-діагностувального, змістово-операційного, результативнооцінювального. Відповідно до виділених блоків визначено педагогічні умови їх реалізації, що відповідають складовим ІКТ-компетентності та блокам моделі методичної системи. В ході дослідження побудовано модель методичної системи формування ІКТ-компетентності майбутніх фахівців галузі «Культура і мистецтво» на основі дидактичних принципів, концепції компетентнісного підходу та поєднання теорії з практикою.
\end{abstract}

Ключові слова: майбутній фахівець галузі «Культура і мистецтво»; IКТкомпетентність; методична система; педагогічні умови.

Постановка проблеми в загальному вигляді. Розвиток системи освіти України зумовлює оновлення парадигми підготовки фахівців у галузі «Культури і мистецтва» на основі збереження традицій та кращих практик національної системи освіти, а також відповідності іiі до перспективного розвитку інформаційного суспільства та забезпечення якості освіти, адже нині відзначається зростання темпів науково-технічного прогресу, постійним збільшенням обсягу інформації, якою повинен оволодіти фахівець, що детермінує підвищення вимог до якості його підготовки. Вони в свою чергу формуються на концептуальних засадах, визначених у Законах України «Про освіту» (2017), «Про вищу освіту» (2014), «Про культуру» (2011), Стратегії розвитку сфери інноваційної діяльності на період до 2030 року в умовах глобалізаційних викликів та сталого гармонійного розвитку суспільства, де освіту в галузі культури розглядають складною, відкритою до змін, розгалуженою системою мистецьких, творчих, культурно-просвітницьких чи

Професіоналізм педагога: теоретичні й методичні аспекти. - Вип. 14 (Ч. 2). - Слов’янськ, 2021. 
Моделювання методичної системи формування ІКТ-компетентності майбутніх фахівців галузі «Культура і мистецтво»

народно-аматорських закладів та громадських утворень. Разом із тим слід відмітити, що заклади вищої освіти залишаються поза увагою мистецьких та просвітницьких центрів, тоді як саме в них формуються майбутні фахівці з усіх спеціальностей галузі «Культура і мистецтво».

Перспективним напрямом реформування як загальної, так і професійної є інтеграція інформаційно-комунікаційних технологій (IКТ) в освітній процес. Відтак, особливого значення набуває питання розвитку ІКТ-компетентності майбутніх фахівців, зокрема й фахівців галузі «Культура і мистецтво», які мають уміти використовувати сучасні засоби IKT для вирішення практичних професійних завдань і здійснення фахової діяльності на якісно високому рівні. Сучасний майбутній фахівець галузі «Культура i мистецтво» має вільно орієнтуватися в інформаційному освітньому середовищі (IOC) згідно з вимогами державних стандартів, володіти технологічними й інформаційнокомунікаційними прийомами професійної діяльності та навичками їхнього застосування для вирішення практичних завдань, уміти послуговуватись 3 цією метою відповідними до завдань програмними засобами.

3 огляду на це окреслюється необхідність пошуку та реалізації ефективної моделі розвитку ІКТ-компетентності майбутніх фахівців галузі «Культура i мистецтво», обгрунтування педагогічних умов і розроблення методики розвитку їхньої ІКТ-компетентності шляхом упровадження комплексу заходів із підготовки майбутніх фахівців галузі «Культура і мистецтво» щодо набуття професійних навичок застосування IKT. Інформаційно-комунікаційна компетентність майбутнього фахівця в галузі «Культура i мистецтво» стає важливою умовою його успішної професійної діяльності, показником потенційних можливостей у сучасному цифровому суспільстві.

Аналіз останніх досліджень і публікацій. Проблема розвитку IКТкомпетентності майбутніх фахівців у галузі «Культура і мистецтво» у психологопедагогічній літературі знайшла відображення у вирішенні широкого кола теоретичних i прикладних питань. Інформаційна компетентність слугувала предметом наукових пошуків О. Акулової, М. Бершадського, Т. Виноградової, О. Зайцевої, В. Падалки, О. Семьонова, А. Темербекової; а інформаційнокомунікаційна компетентність - П.Беспалова, О. Бігич, Л. Білоусової, А. Гуржія, С. Іванової, Л. Карташової, М. Лапчика, В. Назаренка, І. Сіялової, О. Спіріна, П. Третякова, Г. Федорук, Є. Хеннера й ін.

Інформаційно-комунікаційна компетентність, точніше інформаційнокомунікаційно-технологічна компетентність, або ІКТ-компетентність - це підтверджена здатність особистості використовувати на практиці інформаційно- 
Моделювання методичної системи формування ІКТ-компетентності майбутніх фахівців галузі «Культура і мистецтво»

комунікаційні технології для задоволення власних індивідуальних потреб і розв'язування суспільно-значущих, зокрема професійних, задач у певній предметній галузі (Спірін, 2009).

Тобто, здебільшого дослідники під цим поняттям розуміють доведену здатність працювати індивідуально або колективно, використовуючи інструменти, ресурси, процеси та системи, які відповідають за доступ та оцінювання інформації (відомостей та даних), отриманої через будь-які медіаресурси, та використовувати таку інформацію для вирішення проблем, спілкування, створення інформованих рішень, продуктів і систем, а також для отримання нових знань (Овчарук, 2014). Ми у своєму дослідженні підтримуємо ці підходи та використовуємо їх у формуванні ІКТ-компетентності майбутніх фахівців галузі «Культура і мистецтво».

Формулювання цілей статті (постановка завдання). Попри вагомість здобутків науковців у вказаній сфері, залишаються недостатньо осмисленими питання розвитку IКТ-компетентності майбутніх фахівців у галузі «Культура i мистецтво», підвищення їхнього рівня щодо використання IКТ, а також визначення критеріїв і рівнів ІКТ-компетентності майбутніх фахівців у галузі «Культура і мистецтво» в процесі професійної підготовки. Потребують обгрунтування й педагогічні умови розвитку ІКТ-компетентності майбутніх фахівців у галузі «Культура і мистецтво». Таким чином, окреслена проблема видається актуальною та затребуваною.

Посилює перспективність наукового аналізу процесу розвитку IКТкомпетентності майбутніх фахівців у галузі «Культура і мистецтво» у закладах вищої освіти наявність на сучасному етапі їх цифрового та інформаційнокомунікаційного розвитку низки певних протиріч, зокрема між:

- стрімким розвитком інформаційного суспільства та недостатньою підготовленістю майбутніх фахівців у галузі «Культура і мистецтво» до виконання професійних обов'язків в умовах інформатизації;

- потребою підвищення рівня цифрової грамотності майбутніх фахівців у галузі «Культура і мистецтво» і наявним у них рівнем володіння ІКТ, необхідним для виконання їхніх професійних завдань;

- стандартизацією розвитку ІКТ-компетентності майбутніх фахівців у галузі «Культура і мистецтво» та недостатньою розробленістю методики іiі формування, навчально-методичного та матеріально-технічного забезпечення.

Результати дослідження. Розглянемо структуру та обгрунтуваня теоретичних основ моделювання змісту методичної системи формування ІКТкометентності майбутніх фахівців галузі «Культура і мистецтво».

Професіоналізм педагога: теоретичні й методичні аспекти. - Вип. 14 (Ч. 2). - Слов’янськ, 2021. 
Моделювання методичної системи формування ІКТ-компетентності майбутніх фахівців галузі «Культура і мистецтво»

У навчальній i науково-педагогічній літературі до теперішнього часу тривають дискусії щодо трактування терміну «методична система»; немає також чіткого уявлення щодо іiі структури й функцій. Наприклад, за визначенням А. Пишкало, який вперше ввів це поняття, методична система навчання складається із п’яти ієрархічно підлеглих компонентів: цілей, змісту, методів, засобів, організаційних форм навчання. Причому, на його думку, функціонування системи підпорядковано як закономірностям, пов'язаним із іiі внутрішньою будовою (коли зміна одного чи декількох іiі компонентів спричинює зміни всієї системи), так і закономірностям, пов'язаним із зовнішніми зв'язками системи, оскільки кожна система функціонує на певному соціальному та культурному фоні.

В. Плахотник під методичною системою розуміє «...сукупність спеціально організованих засобів навчання, яка на основі відібраного змісту ... у взаємодії з найближчим середовищем сприяє досягненню навчальних цілей» (Плахотник, 2012). А оскільки такі системи виявляються надзвичайно складними за організацією, є відкритими та стохастичними (ймовірнісними), то визначити точні результати їх функціонування, на його думку, виявляється практично неможливим.

С. Гончаренко вважає, що методична система - це впорядкована сукупність взаємопов'язаних i взаємозумовлених методів, форм i засобів планування, проведення контролю, аналізу та коригування навчального процесу, спрямованих на підвищення ефективності навчання (Гончаренко, 2011). 3 позицій системного підходу методична система навчання являє собою єдиний комплекс, який дозволяє моделювати процес навчання і виховання.

Таким чином, під методичною системою розуміємо сукупність взаємопов'язаних і взаємообумовлених компонентів (цільового, аналітикодіагностувального, змістово-операційного, результативно-оцінювального), спрямовану на підвищення рівня сформованості ІКТ-компетентності майбутніх фахівців галузі «Культура і мистецтво». А до основних етапів іï проектування відносимо виявлення основних компонентів системи (підсистем) та їхніх взаємозв'язків; безпосереднє проектування кожного 3 компонентів системи; експериментальну апробацію розробленої методичної системи та її коригування залежно від проміжних результатів.

Нами було проаналізовано науково-методичну літературу, присвячену проблемам підготовки майбутніх фахівців галузі «Культура i мистецтво», власний професійний досвід, вимоги працедавців, практику співпраці $3 В О$ та мистецьких агенцій через кластерну взаємодію, проведення спільних заходів. Це 


\section{Ф. АПШАЙ}

Моделювання методичної системи формування ІКТ-компетентності майбутніх фахівців галузі «Культура і мистецтво»

все дало змогу визначити основні складові моделі формування фахової компетентності майбутніх фахівців галузі «Культура і мистецтво». В структурі цілісної системи, що моделює ІКТ-компетентність фахівця необхідно виділити вхідний i вихідний параметри: особистість, яка потребує професійних знань через низку причин, фахівець, який володіє якостями, сформованими за певною моделлю, та професійна компетентність якого пройшла експертизу. Відповідно, вхідний параметр зумовлений суспільною потребою, а вихідний параметр її задоволенням.

Проектування методичної системи навчання у ЗВО майбутніх фахівців галузі «Культура і мистецтво» передбачає врахування структури самої IКТкомпетентності (рис. 1).

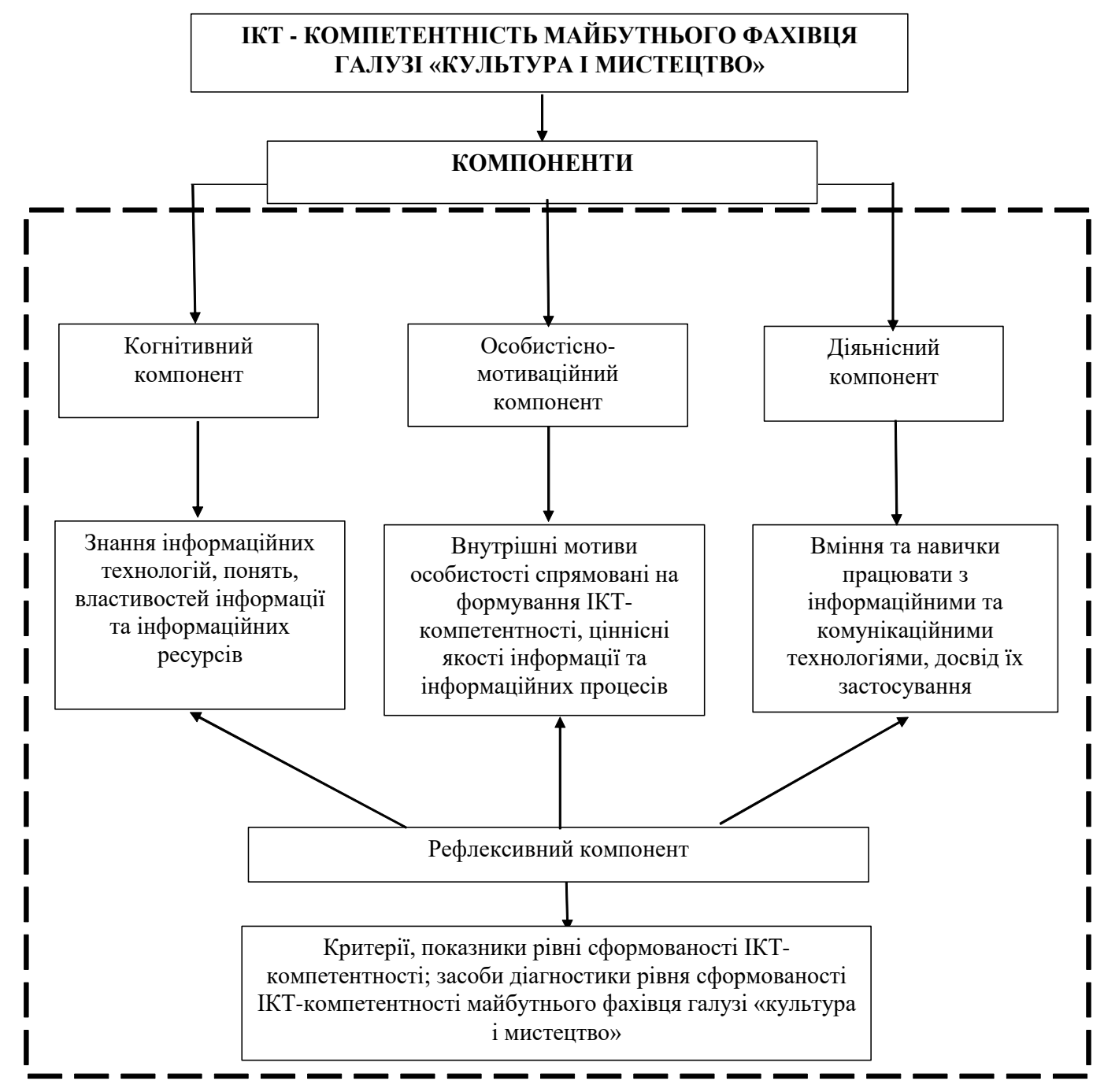

Рис. 1. Структура IКТ- компетентності майбутніх фахівців галузі «Культура і мистеиттво» 
Моделювання методичної системи формування ІКТ-компетентності майбутніх фахівців галузі «Культура і мистецтво»

Отже, як стверджує Є. Лодатко, єдиною реальною можливістю для дослідження педагогічного явища (об'єкта або процесу) є його формалізація (схематизація і спрощення) в такий спосіб, який дозволяв би відстежувати ті його характеристики, які відіграють роль визначальних у дослідженні і підлягають вивченню, оцінюванню й управлінському впливу (Лодатко, 2011).

Модель формування ІКТ-компетентності здобувачів вищої освіти ми розглядаємо як підсистему відкритого типу професійної компетентності, вбудовану в контекст цілісної педагогічної системи закладу освіти. Модель чітко орієнтована на спільну мету- формування ІКТ-компетентності майбутніх фахівців галузі «Культура і мистецтво» представлено на рис. 2 і відповідно включає цільовий, аналітико-діагностувальний, змістово-операційний та результативно-оцінювальний блоки.

В основу моделі методичної системи формування ІКТ-компетентності майбутніх фахівців галузі «Культура і мистецтво» покладено такі дидактичні принципи: принцип наступності i неперервності навчання; принцип доповнюваності; принцип зв'язку теорії з практикою; принцип застосування засобів наочності у навчанні; принцип міцності оволодіння IКТ-компетентністю, які в сукупності забезпечують основу цільового блоку для успішної реалізації наступних складових.

Аналітико-діагностувальний блок необхідний для того, щоб визначити вхідний рівень ІКТ-компетентності майбутніх фахівців різних спеціальностей галузі «Культура і мистецтво», адже вони вступають на навчання 3 різних закладів освіти і мають різний рівень як теоретичних знань, так і практичних умінь використання комп'ютерної техніки.

Змістово-операційний блок є орієнтовною схемою діяльності викладача 3 розробки й упровадження форм, методів і засобів формування професійної компетентності майбутніх майбутніх фахівців галузі «Культура і мистецтво»; традиційних і інноваційних методів навчання; використання засобів навчання на засадах інтегральної єдності інформаційно-комунікаційних та педагогічних технологій.

Результативно-оцінювальний блок відображає успішність функціонування пропонованої структурно-процесуальної моделі та пов'язаний з прогнозуванням очікуваного результату.

Відповідно до виділений блоків визначено педагогічні умови їх реалізації:

- мотивація студентів до підвищення рівня сформованості ІКТкомпетентності; 
Ф. АПШАЙ

Моделювання методичної системи формування ІКТ-компетентності майбутніх фахівців галузі «Культура і мистецтво»

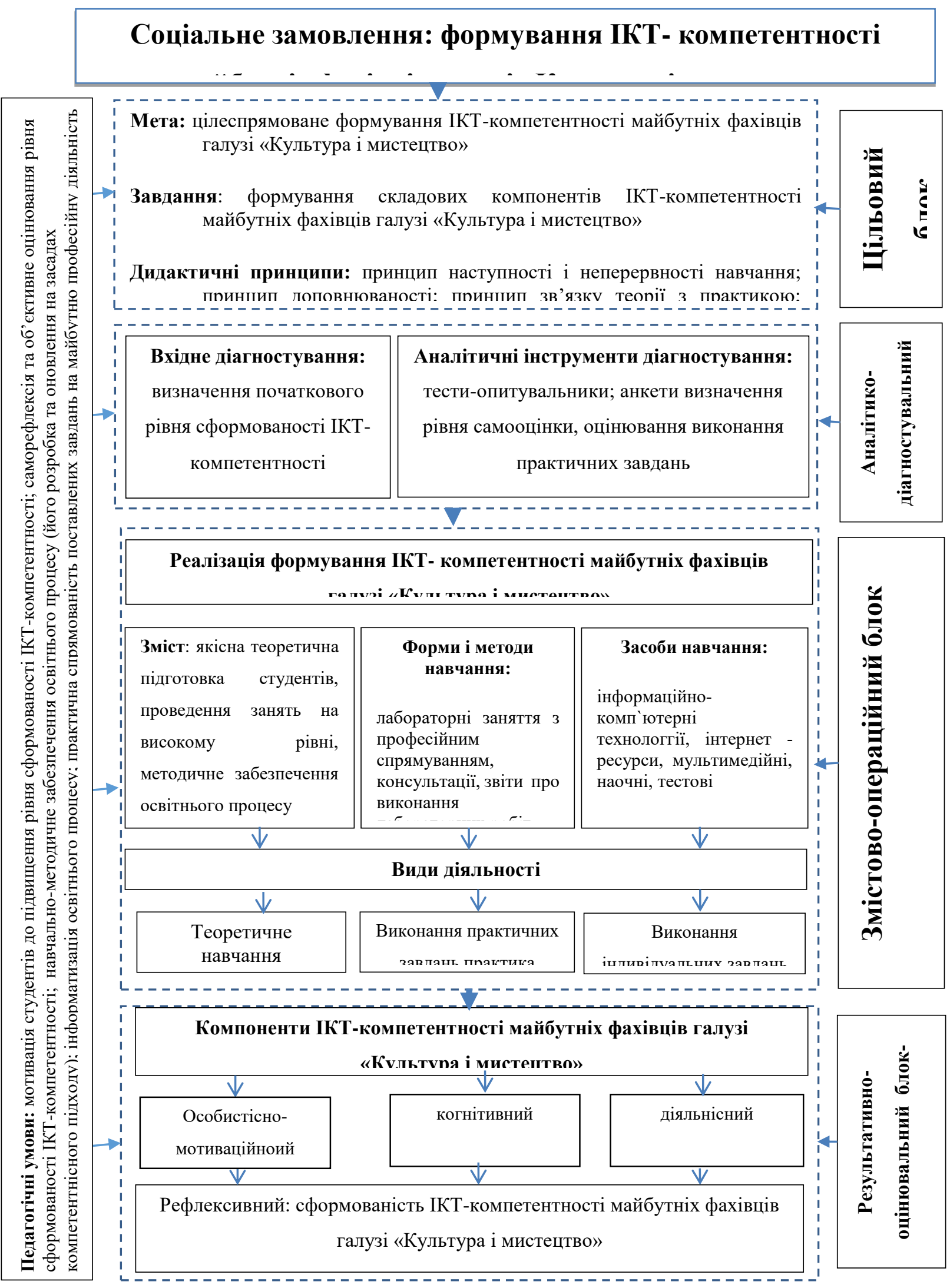

Рис.1. Структурно-процесуальна модель методичної системи формування IКТкомпетентності майбутніх фахівців галузі «Культура і мистецтво»»

Професіоналізм педагога: теоретичні й методичні аспекти. - Вип. 14 (Ч. 2). - Слов’янськ, 2021. 
Моделювання методичної системи формування ІКТ-компетентності майбутніх фахівців галузі «Культура і мистецтво»

- саморефлексія та об’єктивне оцінювання рівня сформованості ІКТкомпетентності;

- навчально-методичне забезпечення освітнього процесу (його розробка та оновлення на засадах компетентнісного підходу);

- інформатизація освітнього процесу;

- практична спрямованість поставлених завдань на майбутню професійну діяльність.

Висновки 3 дослідження і перспективи подальших розвідок у цьому напрямі. Запропонована модель формування професійної компетентності майбутніх фахівців галузі «Культура і мистецтво»є процесуальною і враховує різні підходи до моделювання. У ній об'єкт - ІКТ-компетентність - формується за основними іiі компонентам через систему практичної підготовки в умовах освітнього процесу. При цьому передбачається, що об'єкт нерозривно пов'язаний 3 його носієм, а саме суб'єктом - студентом, який, здійснюючи навчальну i самостійну діяльність, реалізує іiі функції, чим формує компоненти IКТкомпетентності.

Отже, в ході дослідження встановлені й обгрунтовані компоненти методичної системи формування ІКТ-компетентності майбутніх фахівців галузі «Культура і мистецтво», об'єднані в єдине ціле на основі дидактичних принципів, концепції компетентнісного підходу та професійній орієнтації навчання.

\section{СПИСОК ВИКОРИСТАНИХ ДЖЕРЕЛ}

1. Гончаренко, С.У. (2011). Украӥнський педагогічний енщиклопедичний словник. Видання друге, доповнене й виправлене. Рівне: Волинські обереги.

2. Лодатко, С.О. (2011). Педагогічні моделі, педагогічне моделювання і педагогічні вимірювання: that is that? Вища освіта України: Теоретичний та науково-методичний часопис, 3 (1), 339-344.

3. Плахотник, В.М. (2012) Методична система i підручник. Анотовані результати науково-дослідної роботи Інституту педагогіки НАПН України за 2011 рік: наукове видання. К., Ін-т педагогіки, 179-180.

4. Положення про електронні освітні ресурси : затверджено Наказом Міністерства освіти i науки, молоді та спорту України № 1060 від 01.10 .2012 p. URL: http://zakon2.rada.gov.ua /laws/show/z1695-12..

5. Про вищу освіту : Закон України від 01.07.2014 p. № 1556-VII. URL: https://zakon.rada.gov.ua/laws/show/1556-18\#Text.

6. Про культуру : Закон України від 14.12.2010 p. № 2778-VI URL: https://zakon.rada.gov.ua/laws/show/2778-17\#Text.

7. Про освіту : Закон України від 05.09.2017 p. № 2145VIII. URL: https://zakon.rada.gov.ua/laws/show/2145-19\#Text.

8. Про схвалення Стратегії розвитку сфери інноваційної діяльності на період до 2030 року: Розпорядження КМУ від $10 \quad$ липня 2019 p. № 526-p URL:https://zakon.rada.gov.ua/laws/show/526-2019-\%D1\%80\#Text. 
Моделювання методичної системи формування ІКТ-компетентності майбутніх фахівців галузі «Культура і мистецтво»

9. Спірін, О.М. (2009) Інформаційно-комунікаційні та інформативні компетентності як компоненти системи професійно-спеціалізованих компетентностей майбутнього вчителя інформатики. Інформаційні технології $i$ засоби навчання. 5 (13). URL: http://www.ime.eduua.net/em.html.

10. Формування інформаційно-комунікаційних компетентностей у контексті євроінтеграційних процесів створення інформаційного освітнього простору (2014): Посібник. За заг. ред. Бикова В. Ю., Овчарук О. В. Київ: Атіка

\title{
MODELING OF THE METHODICAL SYSTEM OF FORMATION OF ICT- COMPETENCE OF FUTURE PROFESSIONALS OF "CULTURE AND ART"
}

\author{
Fedir Apshay \\ Postgraduate $\mathrm{PhD}$ student \\ Rivne State University for the Humanities, \\ Rivne, Ukraine \\ ORCID ID 0000-0002-9789-464X \\ apshar_fv@ukr.net
}

\begin{abstract}
The training of professionals of "Culture and Arts" for activities in the information society is based on the regulatory framework, where culture education is considered in the context of integration of information and communication technologies (ICT) into the educational process. tasks and professional activities. Future professionals of "Culture and Art" must be able to navigate in the information educational environment, have information and communication techniques and skills, be able to use software for this purpose. Based on the analysis of approaches to the formation of ICTcompetence of future professionals of "Culture and Art" in the psychological and pedagogical literature, it was found that ICT-competence is a proven ability of individuals to use information and communication technologies to meet their individual needs and development. professional tasks. It is expedient to develop a model of the methodical system of formation of ICT-competence of future professionals of "Culture and Art", to ensure the implementation of pedagogical conditions of its formation. It is also necessary to resolve a number of contradictions, in particular between the development of the information society and insufficient training of future professionals of "Culture and Art" to perform professional duties in informatization, the need to increase their digital literacy, development of methods for its formation. Scientific approaches to designing the model of the methodical system of formation of ICT-competence of future professionals of "Culture and Art" are used, its definition is made. The structure of ICT-competence of future professionals of "Culture and Art" includes the following components: personal-motivational, cognitive, activity, reflexive. Under the methodological system we understand a set of interconnected and interdependent components (target, analytical-diagnostic, content-operational, result-evaluation), aimed at increasing the level of ICT-competence of future professionals of "Culture and Art". In accordance with the selected blocks, the pedagogical conditions of their implementation are determined, which correspond to the components of ICT-competence and blocks of the methodological system model.
\end{abstract}

Key words: future professional of "Culture and Art"; ICT-competence; methodical system; pedagogical condition.

\section{REFERENCES}

1. Honcharenko, S.U. (2011). Ukrainskyi pedahohichnyi entsyklopedychnyi slovnyk. Rivne: Volynski oberehy.

2. Lodatko, Ye.O. (2011). Pedahohichni modeli, pedahohichne modeliuvannia i

Професіоналізм педагога: теоретичні й методичні аспекти. - Вип. 14 (Ч. 2). - Слов’янськ, 2021. 


\section{Ф. АПШАЙ}

Моделювання методичної системи формування ІКТ-компетентності майбутніх фахівців галузі «Культура і мистецтво»

pedahohichni vymiriuvannia: that is that? Vyshcha osvita Ukrainy: Teoretychnyi ta naukovometodychnyi chasopys, 3 (1), 339-344.

3. Plakhotnyk, V.M. (2012). Metodychna systema i pidruchnyk. Anotovani rezultaty naukovo-doslidnoi roboty Instytutu pedahohiky NAPN Ukrainy za 2011 rik. Kyiv, In-t pedahohiky, $179-180$.

4. Polozhennia pro elektronni osvitni resursy : zatverdzheno Nakazom Ministerstva osvity i nauky, molodi ta sportu Ukrainy № 1060 vid 01.10.2012r. URL: http://zakon2.rada.gov.ua /laws/show/z1695-12.

5. Pro vyshchu osvitu : Zakon Ukrainy vid 01.07.2014 r. № 1556-VII. URL: https://zakon.rada.gov.ua/laws/show/1556-18\#Text.

6. Pro kulturu: Zakon Ukrainy vid 14.12.2010 № 2778-VI URL: https://zakon.rada.gov.ua/laws/show/2778-17\#Text.

7. Pro osvitu : Zakon Ukrainy vid 05.09.2017 r. № 2145-VIII. URL: https://zakon.rada.gov.ua/laws/show/2145-19\#Text (data zvernennia: 05.05.2021).

8. Pro skhvalennia Stratehii rozvytku sfery innovatsiinoi diialnosti na period do 2030 roku: Rozporiadzhennia KMU vid 10 lypnia 2019 r. № $526-\mathrm{r}$ URL:https://zakon.rada.gov.ua/laws/show/526-2019-\%D1\%80\#Text (data zvernennia: 08.05.2021).

9. Spirin, O.M. (2009). Informatsiino-komunikatsiini ta informatyvni kompetentnosti yak komponenty systemy profesiino-spetsializovanykh kompetentnostei maibutnoho vchytelia informatyky. Informatsiini tekhnolohii $i$ zasoby navchannia, 5 (13), URL: http://www.ime.eduua.net/em.html.

10. Formuvannia informatsiino-komunikatsiinykh kompetentnostei u konteksti yevrointehratsiinykh protsesiv stvorennia informatsiinoho osvitnoho prostoru (2014) : Posibnyk. Za zah. red. Bykova V.Yu., Ovcharuk O.V. Kyiv: Atika

Матеріали надійшли до редакції 10.05.2021 р. 